\title{
Numerical Analysis of Solar Roadways using ANSYS
}

\author{
A.Hemamathi, M.Usharani, Seena Simon, I.Lavanya, M.Raja Rajeshwari
}

\begin{abstract}
Today there are more consequences in climate change due to over utilization of fossil fuels thus leading to serious impact on environment. So there is a need for an alternative solution to reduce the consumption of such non renewable resources. One such effort made in the field of Highway is the development of "Solar Roadways" which can be an alternative solution. Solar roads combine different solution in one - it can help us to improve the production of electricity using solar panels, to provide a digital platform for our future nation's projects like Smart Cities and to facilitate the emerging electric cars that replaces the petrol driven vehicles and much more. This approach through this paper can offer many additional benefits to the people, environment and will contribute for the sustainable development to a larger extent. A rural road incorporating solar panels has been fabricated and a finite element analysis of the model of pavement is done using ANSYS software and loads for rural roads are applied as per IRC standards. Parameters such as stress, strain and deformation are investigated and it is found that the results are well within the permissible limits.
\end{abstract}

Keywords: Smart Grid, Ansys, Arduino, Piezoelectric sensor, Load cell.

\section{INTRODUCTION}

\section{The Earth's climate has changed over history. Just in} 650,000 years there has been a seven cycles of glacial advance and retreat since the last ice age that ended in around 7000 years ago. This abrupt situation around the world is due to increase in temperature. Nowadays, climatic change has been showing diverse effects in economy, health and communities in many ways. Scientist have warned that disastrous situation will take place in the coming years if this issue is not taken into serious concerns; hence various methods should be adopted in various fields to overcome the climate change taking place all around the world. Hence a technology is

Revised Manuscript Received on November 27, 2019

* Correspondence Author

A.Hemamathi*, Department of civil Engineering, R.M.K Engineering college, Thiruvallur district, Tamilnadu, India. Email: a.hemamathi@gmail.com

Dr.M.Usharani, Department of civil engineering, R.M.K Engineering college, Thiruvallur district, Tamilnadu, India. Email: uim.ce@rmkec.ac.in

Seena Simon, Department of civil Engineering, R.M.K Engineering college, Thiruvallur district, Tamilnadu, India. Email: ssn.civil@rmkec.ac.in

I.Lavanya, Student, Department of Civil Engineeirng, R.M.K Engineering college, Tamilnadu, India. Email: lavsiyppn@gmail.com

M.Raja Rajeshwari, Student, Department of Civil Engineeirng, R.M.K Engineering college, Tamilnadu, India. being introduction in the field of roadways that meets the energy production and also is implemented with good traffic assistance to reduce road accidents all over the world.

During 2015, a particularly bad year for our country the heat waves killed around 2000 Indians and at the month of December Chennai has faced a disastrous flood killing many lives and severe damage to the property. These effects are simply due to nothing but a simple phenomenon called all over the world is nothing but climatic change that leads to rise in temperature on the Earth's surface. The cause for such change in India is due to increased population explosion and continuous carbon emission due to emergency of numerous industries in our country. A rise of around $2.25^{\circ} \mathrm{C}$ took place at the particular year across South Asia, including India says an International study published in the year 2016. And the situation continues year by year with an increase in temperature of $10^{\circ} \mathrm{F}$ a global temperature rises all over the world, including India.

A. Anti - Global Warming Measures: In concerns with these activities the two major industries that are the key to global warming are - vehicular emission and energy production (India's major energy production is from the Thermal Power Plants). Thus, measures are to be aken to reduce the impact from the above two sectors by reducing the pollution. It can be done by increasing the usage of renewable resource like sun, wind, hydro power etc. in spite of usage from nonrenewable resources like coal there by cut down the emission of these gases to half.

B. Traffic Characteristics of India: India, is not among the countries cause for increase in global temperature but also road accidents are increasing year by year according to the current road statistics. In the year of 2015, there was about 5 lakh road accidents in India killing around 1.5 lakh people and about 5 lakh people got injured as per the survey taken. And it is being said that the increase in $2 \%$ of road network in India year by year has literally been increasing the level of road accidents to about $28 \%$ as per the recent studies. 


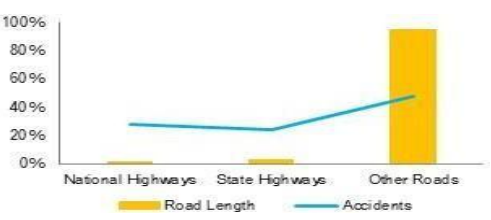

Fig 1. Share of Road Network Vs Road Accident in 2015.

\section{SOLAR ROADWAYS}

As per the Bill passed by the Indian Government, Smart cities are to be established all over the country. Solar Roadways is a company based started by Scott and Julie Brusaw in the early 2009 in U.S. This idea can be implemented in the Smart city in our country where the Asphalt based roads with structurally - engineered solar panel. Roads are built in such a way that they can illuminate themselves and are provided with intelligent traffic assistance to reduce the road accidents and help the driver to ride safely. Consumption of non renewable resource for power production can be reduced in place if solar panels are used where directly electricity can be generated from the roads without the usage of grids. Therefore, initially idea can be developed by just placing the solar panel on the road and provide intelligent traffic assistance and it can be extended further by connecting IoT based technology along with it.

The layers of Solar Roadways are:

$$
\begin{aligned}
& \text { 1. Road Surface Layer } \\
& \text { 2. Electronic Layer } \\
& \text { 3. Base plate Layer }
\end{aligned}
$$

i. Road Surface Layer: Translucent and high-strength glass, it is rough enough to provide sufficient traction, yet still passes sunlight through to the solar collector cells embedded within, along with LEDs and a heating element. This layer needs to be capable of handling today's heaviest loads under the worst of conditions and to be weatherproof, to protect the electronics layer beneath it. Solar Road Panels are made of tempered glass.

ii. Electronic Layer: The electronic layer used in the model consists of several components:

$\begin{array}{ll}\text { i. } & \text { Solar panel 10V } \\ \text { ii. } & \text { Arduino UNO board } \\ \text { iii. } & \text { TP4056 charge controller } \\ \text { iv. } & \text { Boost converter } \\ \text { v. } & \text { Piezoelectric sensor } \\ \text { vi. } & \text { LCD 16*2 display } \\ \text { vii. } & \text { Piezoelectric load cell } \\ \text { viii. } & \text { Street lights }\end{array}$

Fig 2 Block Diagram of Electronic layer

1. Solar Panel 10V: Solar panel work on photovoltaic effect where the light captured from the sun is converted into electricity. The solar panel used in the model has $10 \mathrm{~V}$ capacity. The dimensions of solar panel are $8.0 \mathrm{~cm} \times 3.5 \mathrm{~cm}, 10$ panels are interlinked and placed one after another.

2. Arduino UNO Board: Arduino Uno a microcontroller board is based on 8-bit ATmega328P microcontroller. Along with ATmega328P, it consists of other components they are crystal oscillator, serial communication, voltage regulator, etc. to support the microcontroller. Arduino Uno has 14 digital input/output pins (out of which 6 can be used as PWM outputs), 6 analog input pins, USB connection, Power barrel jack, ICSP header and reset button. It has analog to digital converter.

3. TP4056 Charge Controller: The TP4056 a complete constant-current/voltage linear charger for single cell lithium-ion batteries. Its SOP package and low external component count make the TP4056 ideally suited for portable applications. Furthermore, the TP4056 can work within USB and wall adapter. No blocking diode is required due to the internal PMOSFET architecture and have to prevent negative Charge Current Circuit. Thermal feedback regulates the charge current tolimit the die temperature during high power operation or high ambient temperature. The charge voltage is fixed at $4.2 \mathrm{~V}$, and the charge current can be programmed externally with a single resistor. The TP4056 automatically terminates the charge cycle when the charge current drops to 1/10th the programmed value after the final float voltage is reached.

4. Boost Converter: A boost converter (step-up converter) is a DC-to-DC power converter that steps up voltage (while stepping down current) from its input (supply) to its output (load). It is a class of switched - mode power supply (SMPS) containing at least two semiconductors (a diode and a transistor) and at least one energy storage element: a capacitor, inductor, or the two in combination. To reduce voltage ripple, filters made of capacitors (sometimes in combination with inductors) is normally added to such a converter's output (load-side filter) and input (supply-side filter).

5. Piezoelectric sensor: The piezoelectric sensor is a device used to the piezoelectric effect. This sensor measures the change of pressure, force, temperature, strain and acceleration. Piezoelectric effect is converted into an electrical charge. When any obstacles touch the sensor it is displayed on the LCD as "Obstacle Detected GO SLOW". 


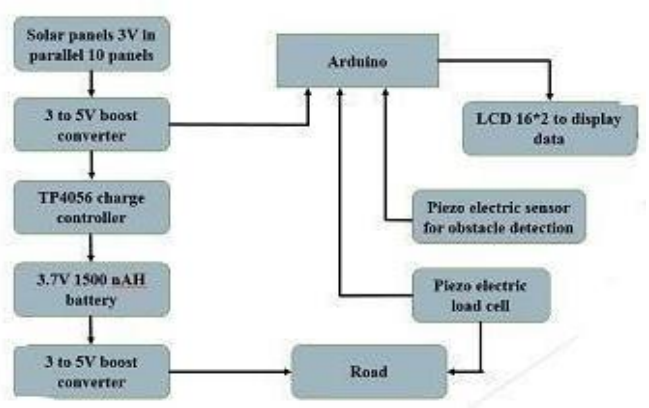

Fig 4. Circuit Diagram for Piezoelectric sensor

6. LCD 16*2 Display: Liquid Crystal Display is an

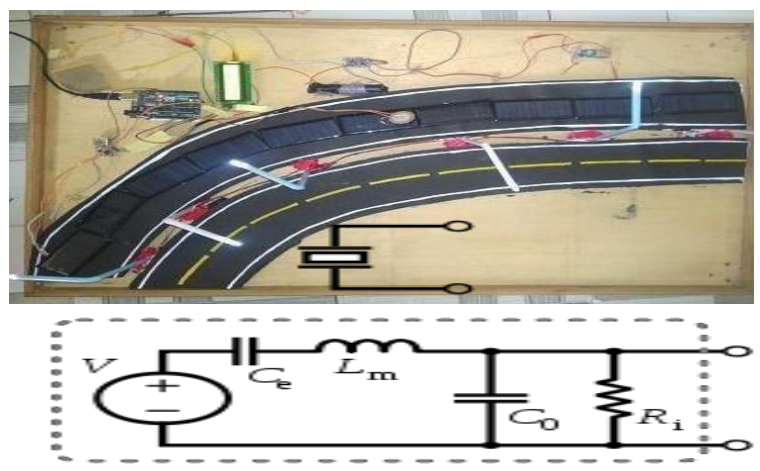

electronic module and finds wide range of application. The LCD $16 * 2$ is the widely used screen size to display data. Here it displays the output from the Arduino, which is connected to the piezoelectric load cell and piezoelectric sensor and also the voltage output from the

7. Piezoelectric load cell: Piezoelectric load cells work on the principle of deformation as the strain gauge load cells, but a voltage output is generated by the basic piezoelectric material - proportional to the deformation of load cell. Here in model, in the place of load cell piezoelectric sensor is used where pressure limit is set in

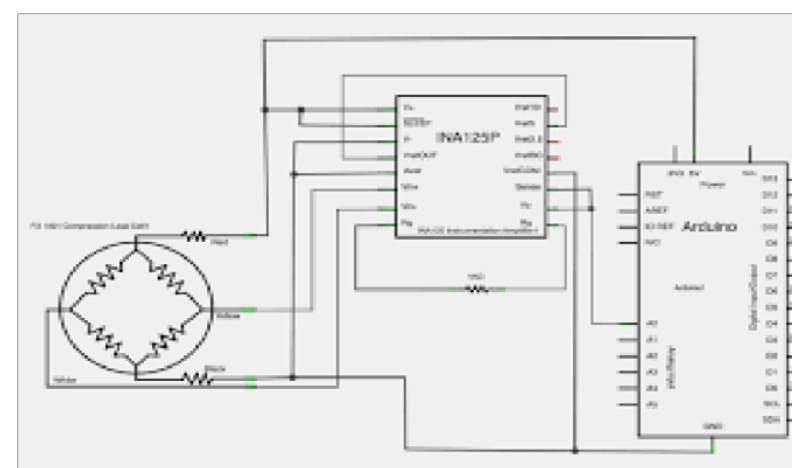

terms of weight. If a load of pressure having an analog value above 60 is sensed by the sensor it is displayed as "Over Weight" on the LCD.In real time load cell is placed below the load surface which is set with a load limit and detects load that goes above it.

Fig 5 Load cell with Arduino

8. Street lights: Street lights are placed on the sides of the road, are connected to the solar roadways solar panels.

directly to receive the electricity that is useful during night. If solar cell is to be used in real time snow management system can be done where deicing technique is used. Drains are placed at the sides to drain the water during rainy season so that electronic layer is not affected.

Fig 6 Fabricated model

iii. $\quad$ Base plate Layer: The Base plate layer used in the solar roadway is made of recyclable material, here thermocol or recyclable rubber waste is used as a base layer. The function of the base layer is to protect the electronic layer from the subgrade. Base plate layer provided is usually weatherproof. This layer distributes the power and signals to and from the panels. Drains are provided to drain the water to protect the electronic layer.

\section{FEATURES OF SOLAR ROADWAY}

The following are the features of solar roadway:
i. Illuminated roads
ii. On the go charging
iii. Traffic Assistance
iv. Smart Grid

A. Illuminated Roads: LEDs are embedded in the electronic layer directly and they are set in a way to display signals on the surface of the road that ensures safe driving during night time.

B. On the go Charging: Electric cars are provided with induction plate that enables to charge the vehicle while moving on the surface itself. In some cases, charging bays are provided that helps to charge the vehicle.

C. Traffic Assistance: LEDs enable to transfer messages on the surface of the road itself that alerts the driver and controls accident rate. Load cell placed below the road surface alerts the driver if there is any sudden change of load on the surface.

D. Smart Grid: Removes the need for power grid, overhead cables and wires due to network congestion occurring due to the transmission of electricity, cost of transmission towers are reduced.

\section{CONTROVERSIES}

The following are the controversies of solar roads:

i. $\quad$ Road Safety




\section{ii. Road Durability \\ iii. Initial cost}

A. Road Safety: Driving or walking on texture glass, is different from asphalt roads and hence it is to subjected to more test.

B. Road Durability: Durability is proven by only by 3D modelling analysis. Hence additional durability should be done on the panel.

C. Initial Cost: One sq.ft. 12 x $12=144$ sq.ft.

One panel cost $\$ 6912$

Cost per sq.ft. $=\$ 481 \$=68.93 \mathrm{INR}$

Therefore, $48 * 68.93=$ Rs.3300/sq.ft. Hence cost of solar road per square feet is around Rs. 3300 which is three times more that Asphalt road.

\section{INDIAN ROAD NETWORK}

Indian road network comprises of $1.7 \%$ national highway and $5 \%$ of state highway. If Asphalt roads are replaced by Solar roadways it will produce around 450TWh electricity. But India needs about 910TWh electricity. So, if $10 \%$ of the roads are replaced by solar panels it will meet the electricity need of the country.

\section{ASPHALT ROADS VS SOLAR ROADWAYS}

Table 1 Asphalt Road Vs Solar Roadways

\begin{tabular}{|c|c|}
\hline ASPHALT ROAD & SOLAR ROADWAYS \\
\hline $\begin{array}{c}\text { Initial cost is Rs. } 1102 \\
\text { for Asphalt roads }\end{array}$ & $\begin{array}{c}\text { Initial cost is three times } \\
\text { than that of Asphalt } \\
\text { roads }\end{array}$ \\
\hline $\begin{array}{c}\text { Cost of Asphalt increases } \\
\text { when petroleum cost } \\
\text { increases }\end{array}$ & $\begin{array}{c}\text { No such issues occurs } \\
\text { here. }\end{array}$ \\
\hline $\begin{array}{c}\text { Initial cost is low, but } \\
\text { maintenance cost is } \\
\text { high. }\end{array}$ & $\begin{array}{c}\text { Initial cost is high, but } \\
\text { maintenance cost is low. }\end{array}$ \\
\hline Last for 7 years & Last for 21 years \\
\hline
\end{tabular}

\section{DESIGN OF RURAL ROADS}

The pavement is designed for low volume rural road as per IRC SP 20:2002(Rural roads Manual)

\section{A.Design Parameters (Assumed):}

$\mathrm{P}$ - Number of commercial vehicles as per last count $=198 \mathrm{CVPD}$

$\mathrm{r}-$ Traffic growth rate $=6 \%$ (according to code)

$\mathrm{n}$ - Years between the traffic count and completion of construction $=0$ years

$\mathrm{x}$ - Design Life $=10$ years $B$.

\section{Calculation of $A$ value:}

Design traffic $(A)=P(1+r)^{n+x}$

$$
\begin{aligned}
& =198(1+0.06)^{10} \\
& =198(1.06)^{10} \\
A & =198(1.7908)=354 \text { CVPD. }
\end{aligned}
$$

Total Thickness $=470 \mathrm{~mm}$

Table 2 Thickness of Individual layers

\begin{tabular}{|c|c|c|}
\hline Layer of Pavement & Provision made & Thickness (mm) \\
\hline Subgrade & $\begin{array}{c}\text { Existing } \\
\text { natural } \\
\text { subgrade }\end{array}$ & - \\
\hline Sub - Base & $\begin{array}{c}\text { Granular Sub } \\
- \text { Base }\end{array}$ & 300 \\
\hline Base & $\begin{array}{c}\text { Wet Mix } \\
\text { Macadam }\end{array}$ & 150 \\
\hline $\begin{array}{c}\text { Wearing } \\
\text { Course }\end{array}$ & SDBC & 20 \\
\hline
\end{tabular}

\section{PAVEMENT ANALYSIS}

The pavement was analyzed using finite element software ANSYS to validate the deflection of pavement for various vehicular loading condition. To differentiate the different layers the surface layer was divided into 5 divisions, base layer 10 divisions and sub grade into 15 divisions. Two wheeler, three wheeler and four wheeler loads were applied as concentrated loads on the pavement and the behavior of stresses was studied. the following properties were assigned to different layers of the pavement.

Considering width of road $=5 \mathrm{~m}$

Table 3 Properties of individual layers

\begin{tabular}{|c|r|r|r|c|}
\hline layers & $\begin{array}{r}\text { Modulus of } \\
\text { Elasticity (Pa) }\end{array}$ & $\begin{array}{c}\text { Poisson's } \\
\text { ratio }\end{array}$ & $\begin{array}{c}\text { Density } \\
\left(\mathrm{Kg} / \mathrm{m}^{3}\right)\end{array}$ & $\begin{array}{c}\text { Thickness } \\
(\mathrm{m})\end{array}$ \\
\hline $\begin{array}{c}\text { Surface } \\
\text { layer }\end{array}$ & $33 \mathrm{E} 6$ & 0.27 & 1190 & 0.09 \\
\hline $\begin{array}{c}\text { Base } \\
\text { Layer }\end{array}$ & $23 \mathrm{E} 6$ & 0.49 & 1430 & 0.25 \\
\hline Subgrade & $10 \mathrm{E} 6$ & 0.45 & 1690 & $\infty$ \\
\hline
\end{tabular}

\section{A. Application of load}

As the design is for rural roads two wheeler and three wheeler loads are applied at the nodes.

For Two Wheeler $=1500 \mathrm{~N}$ (downwards)

For Three wheeler $=5500 \mathrm{~N}$ (downwards) 


\section{B. Results}

Results of stress, strain and deformation are shown in figures below:

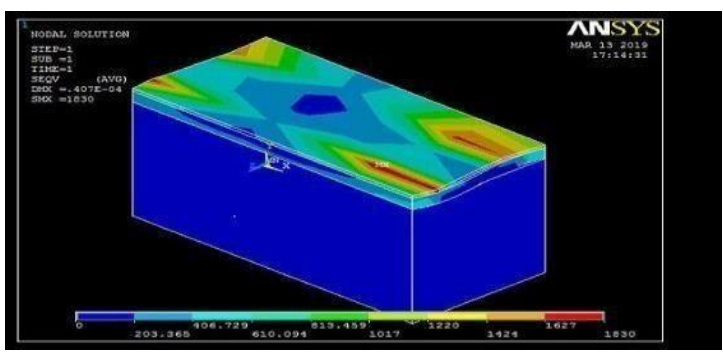

Fig 7 Stress at Surface and Base layer

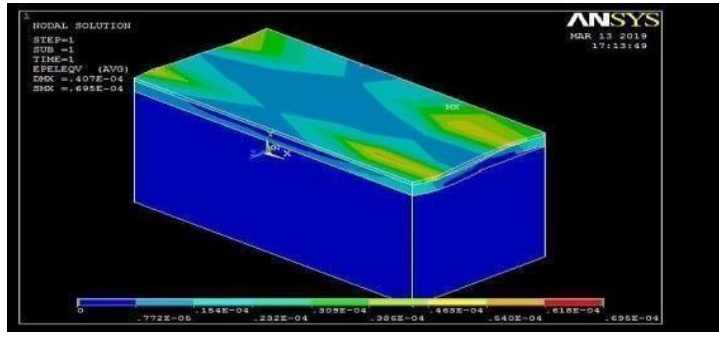

Fig 8 Strain at Surface and Base layer

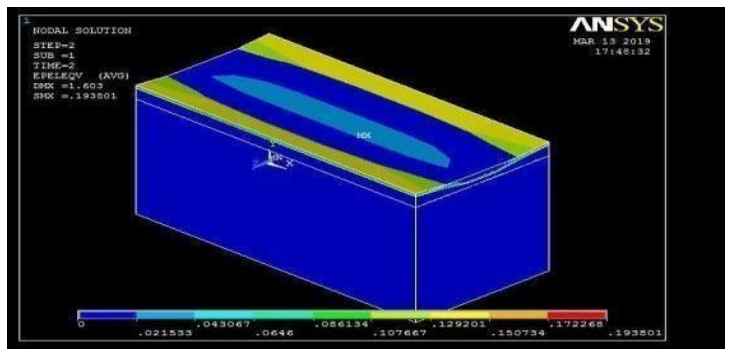

Fig 9 Strain at Surface layer

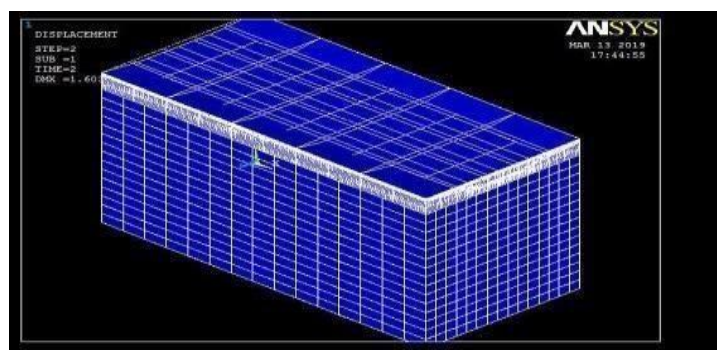

Fig 10 Deformation due to the two wheeler load

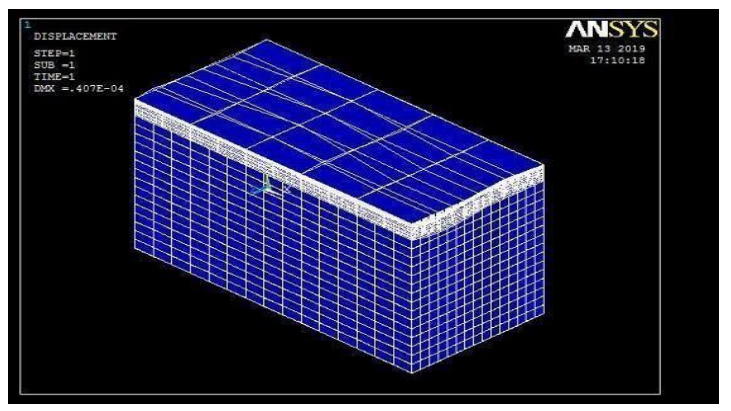

Fig 11 Deformation due to three wheeler load

i. A Fabricated model is made, and sensors are connected to the Arduino to find the load acting on the surface of the pavement and obstacle detection is done.

ii. The sensor was able to sense for any obstruction on the pavement alerting the driver by passing signals through the sensors.

iii. The sensor also gives an alerting signal when the pavement is overloaded. This protects the solar panels from getting damaged.

iv. The ANSYS results has shown that the stresses and strain on the pavement are within the permissible limits, protecting the pavement from getting damaged for the given loading condition.

\section{REFERENCES:}

1. Monalisa Hati, "Solar roadways- an effort to make safe and smart highways", International Advanced Research Journal in Science, Engineering and Technology, Vol. 3, Issue 7, July 2016, pp. 50-53

2. Ashiq Guntupalli, "Intelligent highways (Solar roadways)- rebuilding our infrastructure", International Journal of Interdisciplinary Research and Innovations, Vol. 2, Issue 4, pp: (11-19), Month: October - December 2014

3. Abhishek Rajendra Patila ,Vaibhav Yashwant Khairnara ,Dr.Anil V.Kokatea and Dr.Rajendra S.Narkhedea, "A Novel Route for Construction of Smart Highways by Using Photovoltaic Solar Panels", International journal of research and analytical reviews IJRAR September 2018, Volume 5, Issue 3, pp 491 - 496

4. Alark.A.Kulkerni, "Solar roadways- Rebuilding our infrastructure and economy", International journal of engineering research and applications, 2013.

5. Aaron Seward(2014)" Best of whats new: solar roadways"

6. Sharma and Harinarayana International Journal of Energy and Environmental Engineering, 2013 http://www.journalijeee.com/content/4/1/16

7. Er. Rajeev Ranjan, "Solar Power Roads: Revitalising Solar Highways, Electrical Power and Smart Grids" International Journal of Engineering Research and General Science Volume 3, Issue 1, January-February, 2015, pp. 380-385

8. ANSYS guide, https://studentcommunity.ansys.com/thread/user-manual

9. http://users.abo.fi/rzevenho/ansys $\% 20$ fluent $\% 2018 \% 20$ tutorial $\% 20$ guide. pdf

10. Indian road congress, special publication 20, Rural loads manual, New Delhi 2002.

\section{AUTHORS PROFILE}

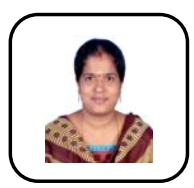

A.Hemamathi, working as Assistant professor at RMK Engineering College has obtained her B.E. (Civil) from Thiagarajar college of Engineering, M.E (Structural Engineering) from Regional Engineering college, Trichirapalli and currently pursuing her Ph.D at Anna University, Chennai. Her area of interests includes but not limited to precast concrete connection, earthquake engineering, design of RC structures. She is a Life member of ISTE, ICI. \& IEI .

Dr.M.Usharani working as a professor at RMK Engineering College, obtained her B.E. (Civil) M.E. (Structural Engineering) and Ph.D (Structural Engineering) all the three from Coinbatore Institute of Technology, Coimbatore. She has about 23 years of experience in teaching for U.G \& P.G and 9 years of experience in construction industry. Totally She has Published 30 Research Papers in International journals, National journals, International and National Conferences. She has authored two books on Structural Analysis I \& II. She is a Life member of ISTE, ICI. \& IEI.

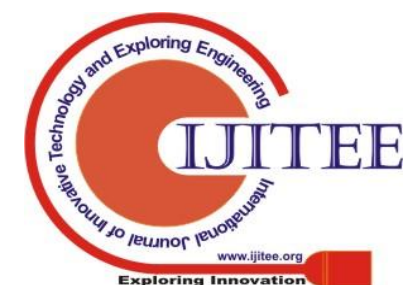


Seena Simon working as Assistant Professor in R. M. K. Engineering College, Kavaraipettai. Completed B.Tech in Civil Engineering from Calicut University in 2009. Completed M.E in Structural Engineering from Anna University in 2012. She is a life member of ISTE.

I.Lavanya is an undergraduate student of Civil Engineering, R.M.K Engineering college. Her area of interest includes structural engineering and application of software in civil Engineering. She is a student member of ISTE, ICI. \& IEI

M.Raja Rajeshwari is an undergraduate student of Civil Engineering, R.M.K Engineering college. Her area of interest includes structural engineering and application of software in civil Engineering She is a student member of ISTE , ICI. \& IEI 